\title{
ACTIVITY OF BETA-GLUCOSIDASE AND LEVELS OF ISOFLAVONE GLUCOSIDES IN SOYBEAN CULTIVARS AFFECTED BY THE ENVIRONMENT1
}

\author{
MERCEDES CONCÓRDIA CARRÃO-PANIZZI² and JOSÉ RENATO BORDINGNON³
}

\begin{abstract}
The enzyme $\beta$-glucosidase hydrolyses the isoflavone glucosides developing aglycones, which are compounds with anticancer effects, that are also related with the astringency observed in soybean flavor. Due to the importance of this enzyme, a study was carried out to determine $\beta$-glucosidase activity in soybean (Glycine $\max (\mathrm{L}$.) Merrill) cultivars with different contents of isoflavone glucosides (enzyme substrate). The enzyme activity was determined in 51 soybean cultivars sowed in Londrina (latitude $23^{\circ} \mathrm{S}$ ), in Paraná State, Brazil, and in the cultivar IAS 5 from soybean production regions of different Brazilian states. Among the cultivars, a range of variability of 176.1 to 96.3 units of enzyme activity (cultivars IAC-2 and Embrapa 2, respectively) was observed. A significant variability among cultivars could suggest genetic differences. In the states of Rio Grande do Sul, Paraná and Mato Grosso do Sul, the cultivar IAS 5 presented similar average of $\beta$-glucosidase activity: 132.1, 131.9 and 132.5 units, respectively. Among locations in the states, the cultivar IAS 5 presented a variability for enzyme activity from 138.8 to 124.8 units, which were statistically different. In spite of statistics, the numerical values were not too different to assume that environmental conditions affected enzyme activity. A non-significative correlation for isoflavone glucoside concentrations and enzyme activity was observed among cultivars.
\end{abstract}

Index terms: environmental effect, Glycine max, aglycones, soybean flavor.

\section{ATIVIDADE DE BETA-GLICOSIDASE E NÍVEIS DE ISOFLAVONÓIDES GLICOSÍDIOS EM CULTIVARES DE SOJA, INFLUENCIADAS PELO AMBIENTE}

\begin{abstract}
RESUMO - A enzima $\beta$-glicosidase hidrolisa os isoflavonóides glicosídeos desenvolvendo agliconas, compostos com ação anticancerígena, que também são relacionados com a adstringência observada no sabor da soja. Pela importância dessa enzima, conduziu-se um estudo para determinar a atividade da $\beta$-glicosidase em cultivares de soja (Glycine max (L.) Merrill) com teores diferenciados de isoflavonóides glicosídeos (substratos da enzima). A atividade enzimática foi determinada em 51 cultivares de soja semeadas em Londrina, latitude $23^{\circ} \mathrm{S}$, no Estado do Paraná, e na cultivar IAS 5, proveniente de regiões produtoras de soja de diferentes estados do Brasil. Entre as cultivares observou-se uma amplitude na variabilidade de 176,1 a 96,3 unidades de atividade enzimática nas cultivares IAC-2 e Embrapa 2, respectivamente. Entretanto, a variabilidade significativa observada entre as cultivares pode estar indicando diferenças genéticas. Nos estados do Rio Grande do Sul, Paraná e Mato Grosso do Sul, a cultivar IAS 5 apresentou atividades similares com valores médios de $\beta$-glicosidase iguais a 132,1, 131,9 e 132,5 unidades, respectivamente. Entre os locais nos estados, a cultivar IAS 5 apresentou variabilidade na atividade da enzima de 138,8 a 124,8 unidades, as quais foram estatisticamente diferentes. No entanto, apesar da estatística, os valores numéricos não foram tão diferentes para assumir que houve influência do ambiente sobre a atividade da enzima. Entre as cultivares, não houve correlação significativa entre o teor de isoflavonóides glicosídeos e a atividade da enzima.
\end{abstract}

Termos para indexação: efeito ambiental, Glycine max, agliconas, sabor da soja.

\footnotetext{
${ }^{1}$ Accepted for publication on June 21, 1999.

${ }^{2}$ Agronomist, Dra., Embrapa-Centro Nacional de Pesquisa de Soja (CNPSo), Caixa Postal 231, CEP 86001-970 Londrina, PR, Brasil. E-mail: mercedes@cnpso.embrapa.br

${ }^{3}$ Pharmaceutical Chemist, M.Sc., Embrapa-CNPSo.
}

\section{INTRODUCTION}

Consumption of soyfoods might protect against hormone and non-hormone-related cancers (Messina et al., 1994). High concentrations of isoflavones in 
urinary excretion of Asian population might be related with reduced incidence of breast and prostate cancer (Adlercreutz et al., 1991; Coward et al., 1993; Xu et al., 1994). In soybean grains the main forms of isoflavones include glucosidic conjugates genistin, malonyl genistin, daidzin and malonyl daidzin, glycitin and malonyl glycitin (Kudou et al., 1991; Wang \& Murphy, 1994b), which are highly variable with environment conditions and soybean cultivars (Kudou et al., 1991; Wang \& Murphy, 1994a; CarrãoPanizzi \& Kitamura, 1995). The aglycone forms, daidzein, glycitein and genistein are developed by the hydrolytic action of the enzyme $\beta$-glucosidase on the glucosidic isoflavone precursors (Matsuura et al., 1989). Some studies have reported the effects of genistein in preventing and inhibiting prostate cancer, as well as its anticancer effect, similar to tamoxifen the anti-estrogenic drug utilized in breast cancer therapy (Peterson \& Barnes, 1991, 1993).

Depending on processing technique, soybean products present different forms and concentrations of isoflavones. Fermented products contain higher levels of aglycones, while non-fermented products have almost exclusively the conjugated glucosidic forms (Coward et al., 1993; Wang \& Murphy, 1994b). Lactic acid fermentation (Matsuda et al., 1992, 1994) and pre-soaking treatments during processing activate the enzymatic process of $\beta$-glucosidase (Matsuura et al., 1989; Ha et al., 1992).

Matsuura et al. (1989) observed that the optimum $\mathrm{pH}$ for production of aglycones, daidzein and genistein, in soymilk was around 6.0 at $50^{\circ} \mathrm{C}$ temperature. Two isoforms of $\beta$-glucosidase $(B, C)$ brought nearly all the hydrolyzing action into daidzin and genistin (Matsuura \& Obata, 1993). The enzyme showed optimum activity at $\mathrm{pH} 4.5$ and $45^{\circ} \mathrm{C}$, and its $\mathrm{pH}$ range of action was 3.5-7.0. The enzyme was also stable from $\mathrm{pH} 4.0$ to 6.0 at $5^{\circ} \mathrm{C}$ (Matsuura et al., 1995).

The substrate isoflavone glucosides exists in relative abundance in soybean grains. A large genetic variability for total amounts of isoflavones glucosides were observed in Brazilian soybean cultivars (Carrão-Panizzi \& Kitamura, 1995; CarrãoPanizzi, 1996a).
This study was carried out to determine $\beta$-glucosidase activity and isoflavone glucosides in soybean cultivars, and to analyze the effects of environmental conditions on the enzyme activity.

\section{MATERIAL AND METHODS}

\section{Plant materials}

In November, 1993, 51 soybean cultivars were sowed at Londrina county (latitude $23^{\circ} 11^{\prime} 50^{\prime \prime}$ S), PR, Brazil, for analysis of $\beta$-glucosidase enzyme activity and total isoflavone glucosides. The first experiment was conducted in a randomized complete block design, replicated two times, and data were analysed according to the model:

$Y_{i j}=m+B_{i}+T_{j}+E_{i j}$

where: $\mathrm{Y}$ represents the observations; $\mathrm{m}$ is the effect of mean; $B_{i}$ is the effect of block; $C_{j}$ is the effect of cultivar; $E_{i j}$ is the residual effect.

For the second experiment, seed samples of cultivar IAS 5 from the 1993/94 yield soybean trials, from different locations of Brazilian soybean production regions that were utilized to determine the effects of genetics and environmental factors on isoflavone content (CarrãoPanizzi, 1996b), were also used to determine these effects on enzyme activity. The three states considered in this experiment with 13 different locations were the following: Rio Grande do Sul (RS): Cruz Alta, Passo Fundo, Santa Rosa, Vacaria; Paraná (PR): Londrina, Ponta Grossa, Mariópolis, Palotina, Cascavel, Campo Mourão; and Mato Grosso do Sul (MS): Campo Grande, São Gabriel do Oeste, Sidrolândia.

Data from this experiment were analyzed as a complete randomized design according to the model:

$\mathrm{Y}_{\mathrm{ijk}}=\mathrm{m}+\mathrm{L}_{\mathrm{i}}+\mathrm{S}_{\mathrm{ij}}+\mathrm{E}_{\mathrm{ijk}}$,

where: $Y$ represents the observations; $m$ is the mean effect; $\mathrm{L}_{\mathrm{i}}$ is the location effect; $\mathrm{S}_{\mathrm{ij}}$ is the location effect within state; and $\mathrm{E}_{\mathrm{ijk}}$ is the residual effect.

Before running the ANOVA, data were evaluated for normal distribution (Shapiro \& Wilk, 1965), homogeneity of variance (Hartley, 1940; Burr \& Foster, 1972), and model additivity (Tukey, 1949). Differences among treatment mean values were determined by using Tukey's test at $\mathrm{P} \leq 0.05$ (Cochran \& Cox, 1957) and by cluster analysis at $\mathrm{P} \leq 0.05$ (Scott \& Knott, 1974). Statistical analysis system 
(SAS Institute, 1995), and Sistema de Análise Estatística SANEST (Zonta et al., 1982) were used for data analysis.

Data of isoflavone glucosides used in correlation analysis were from analysis of high performance liquid chromatography (HPLC) performed in Carrão-Panizzi (1996a, 1996b), since the same samples of those experiments were used to carry out analysis of $\beta$-glucosidase.

\section{Analysis of $\beta$-glucosidase activity}

A modified procedure of Matsuura et al. (1989) was used to determine $\beta$-glucosidase activity, which was monitored with a synthetic substrate p-nitrophenyl- $\beta$ D-glucopiranoside (p-NPG).

Enzyme was extracted from $100 \mathrm{mg}$ samples of ground raw soybeans with $1.5 \mathrm{~mL}$ of citrate buffer $0.05 \mathrm{M}$ ( $\mathrm{pH} 4.5$ ) containing sodium chloride $0.1 \mathrm{M}$ for one hour, at room temperature $\left(20^{\circ} \mathrm{C}\right)$. After centrifugation, $200 \mu \mathrm{L}$ from the supernatant were used directly for enzyme assay.

Substrate of $\beta$-glucosidase was prepared with p-nitrophenyl- $\beta$-D-glucopiranoside $1 \mathrm{mM}$ in sodium phosphate buffer $0.1 \mathrm{M}$ (pH 6.7).

For the enzymatic reaction, $200 \mu \mathrm{L}$ of the substrate and $200 \mu \mathrm{L}$ of the extracts were incubated in test tubes for 2 hours and 30 minutes at $40^{\circ} \mathrm{C}$. After this period the reaction was stopped by addition of $2.0 \mathrm{~mL}$ sodium carbonate $0.25 \mathrm{M}(\mathrm{pH} 9.0)$ and the amount of p-nitrophenol liberated was determined by the yellow color developed in alkaline condition. The absorbances were measured in a spectrophotometer (Hitachi mod. U-2000), at $420 \mathrm{~nm}$ zeroed with water. A blank tube was prepared with $200 \mu \mathrm{L}$ of substrate, $200 \mu \mathrm{L}$ of enzyme extract and $2.0 \mathrm{~mL} \mathrm{Na}_{2} \mathrm{CO}_{3} 0.25 \mathrm{M}$ (pH 9.0).

A unit of enzyme activity was defined as the amount of enzyme which would liberate $1.0 \mathrm{mg}$ of p-nitrophenol after 2.5 hours of reaction in $100 \mathrm{~g}$ of soybean sample.

\section{Analysis of total isoflavone glucosides by HPLC}

From a $100 \mathrm{~g}$ sample of soybean seeds, $30 \mathrm{~g}$ were weighted to form subsamples, with $5 \mathrm{~g}$ taken and milled for 40 seconds in a vibrating sample mill (Heiko mod TI-100). Since traditional soybean processing into food products does not separate seed parts (seed coat, hypocotyl, and cotyledon), for the isoflavone analysis, the entire seed was considered.
The quantitative analysis of isoflavones was conducted in a HPLC (Kitamura et al., 1991; Kudou et al., 1991). One hundred milligrams of milled samples were extracted with $4.0 \mathrm{~mL}$ of $70 \%$ aqueous ethanol containing $0.1 \%$ acetic acid, in screw-capped test tubes, for one hour, at room temperature. After extract centrifugation, a $40 \mu \mathrm{L}$ aliquot of the supernatant was used for HPLC analysis. Analyses of isoflavones were performed on ODS commercially packed columns of reversed phase (Tosoh Corp. Tokyo; TKS-gel ODS-80TM i.d. 4.6 x $250 \mathrm{~mm}$ ).

Elution of isoflavone compounds was performed by a linear gradient system. The initial gradient system consisted of $20 \%$ acetonitrile and $80 \%$ of a $0.1 \%$ acetic acid solution, which reached after $30 \mathrm{~min}$ of elution, proportions of $45 \%$ of acetonitrile and $55 \%$ of acetic acid solution, when all the isoflavones had been detected. The solvent flow rate was $1.0 \mathrm{~mL} / \mathrm{min}$, and the UV absorption was measured at $260 \mathrm{~nm}$. Purified soybean isoflavones were used as standards (Kudou et al., 1991). Isoflavone contents were calculated as mg/100 g (Eldridge \& Kwolek, 1983; Kitamura et al., 1991). Soybean seeds had $11 \%$ to $13 \%$ moisture.

\section{RESULTS AND DISCUSSION}

Soybean cultivars showed a significative variability for $\beta$-glucosidase activity. Cultivars IAC-2, EMGOPA-301, BR-2 and OCEPAR 2 present the highest enzyme activity (165.0 units in average) while cultivars FT-9, Embrapa 20, FT-14 and Embrapa 2 had lower activity (99.1 units, in average) (Table 1). This variability suggests that this differences could be due to genetic factors. In a previous paper, Carrão-Panizzi \& Kitamura (1995) observed that isoflavone glucosides, which are the enzyme substrates, are genetically controlled, although highly variable with environmental conditions. Cultivar Embrapa 20 showed the highest content of isoflavone glucosides, while FT-14 showed low level of these compounds (Table 1). These results suggest noncorrelation between isoflavone glucosides and enzyme activity, which were confirmed by the correlation analysis $(\mathrm{r}=-0.27)$. In dried grains the conjugated isoflavone glucosides are the major forms (Kudou et al., 1991). Unconjugated isoflavones aglycones, daidzein and genistein are formed by hydrolysis of the isoflavone glucoside, under special conditions of processing, 
TABLE 1. Mean values of $\beta$-glucosidase activity (mg of p-nitrophenol/100 $\mathrm{g}$ of samples/2.5 hours) and total isoflavone glucoside $(\mathrm{mg} / \mathbf{1 0 0} \mathrm{g})$ in soybean cultivars sowed in Londrina, PR, in 1993/941.

\begin{tabular}{|c|c|c|}
\hline Cultivar & $\begin{array}{l}\beta \text {-glucosidase } \\
\text { activity }\end{array}$ & $\begin{array}{c}\text { Total isoflavone } \\
\text { glucoside }\end{array}$ \\
\hline IAC-2 & $176.1 \mathrm{a}$ & $61.1 \mathrm{j}$ \\
\hline EMGOPA-301 & $162.5 \mathrm{~b}$ & $81.6 \mathrm{f}$ \\
\hline BR-2 & $161.0 \mathrm{~b}$ & $75.5 \mathrm{~g}$ \\
\hline OCEPAR 2 & $160.5 b$ & $76.3 \mathrm{~g}$ \\
\hline IPAGRO-20 & $157.0 \mathrm{c}$ & $51.3 \mathrm{k}$ \\
\hline Ivorá & $156.6 \mathrm{c}$ & $61.9 \mathrm{j}$ \\
\hline BR-29 & $156.1 \mathrm{c}$ & $65.5 \mathrm{i}$ \\
\hline BR-24 & $155.1 \mathrm{c}$ & $113.1 \mathrm{c}$ \\
\hline BR-12 & $153.3 d$ & $40.4 \mathrm{~m}$ \\
\hline EMGOPA-305 & $152.8 \mathrm{~d}$ & 50.21 \\
\hline $\mathrm{CAC}-1$ & $150.8 \mathrm{~d}$ & $67.7 \mathrm{i}$ \\
\hline BR-8 & $149.3 d$ & 50.01 \\
\hline IAC-13 & $144.5 \mathrm{e}$ & $112.3 \mathrm{c}$ \\
\hline BR-14 & $142.7 \mathrm{e}$ & $71.4 \mathrm{~h}$ \\
\hline Paraná & $141.7 \mathrm{e}$ & $109.2 \mathrm{~d}$ \\
\hline Ivaí & $140.8 \mathrm{e}$ & $76.4 \mathrm{~g}$ \\
\hline Embrapa 1 & $139.8 \mathrm{e}$ & $87.0 \mathrm{f}$ \\
\hline Numbaíra & $139.8 \mathrm{e}$ & $91.7 \mathrm{e}$ \\
\hline FT-Canarana & $139.2 \mathrm{e}$ & 16.80 \\
\hline EMGOPA-302 & $138.0 \mathrm{e}$ & $55.6 \mathrm{k}$ \\
\hline FT-Seriema & $133.3 \mathrm{f}$ & $51.1 \mathrm{k}$ \\
\hline FT-13 & 133.0f & $29.6 n$ \\
\hline CAC-1LD & $131.7 \mathrm{f}$ & - \\
\hline EMGOPA-308 & 131.0f & 48.71 \\
\hline FT-12 & $129.4 \mathrm{f}$ & $92.9 \mathrm{e}$ \\
\hline FT-Manacá & $122.1 \mathrm{~g}$ & $90.3 \mathrm{e}$ \\
\hline EMGOPA-307 & $121.7 \mathrm{~g}$ & $61.7 \mathrm{j}$ \\
\hline IAC-11 & $120.1 \mathrm{~g}$ & 51.6.k \\
\hline EMGOPA-310 & $119.9 \mathrm{~g}$ & $61.4 \mathrm{j}$ \\
\hline EMGOPA-311 & $119.2 \mathrm{~g}$ & $71.6 \mathrm{~h}$ \\
\hline Embrapa 3 & $119.0 \mathrm{~g}$ & 50.11 \\
\hline FT-20 & $118.0 \mathrm{~g}$ & $66.5 \mathrm{i}$ \\
\hline BR-40 & $117.7 \mathrm{~g}$ & 47.01 \\
\hline EMGOPA-313 & $116.2 \mathrm{~h}$ & $76.8 \mathrm{~g}$ \\
\hline BR-1 & $114.2 \mathrm{~h}$ & $69.7 \mathrm{~h}$ \\
\hline BR-3 & $114.1 \mathrm{~h}$ & $42.0 \mathrm{~m}$ \\
\hline Dourados & $113.9 \mathrm{~h}$ & $108.6 d$ \\
\hline CEP 20 & $112.7 \mathrm{~h}$ & $71.5 \mathrm{~h}$ \\
\hline BR-11RC & $110.6 \mathrm{i}$ & $54.6 \mathrm{k}$ \\
\hline FT-Cometa & $108.4 \mathrm{i}$ & $62.1 \mathrm{j}$ \\
\hline GOBR-25 & $108.0 \mathrm{i}$ & $93.7 \mathrm{e}$ \\
\hline EMGOPA-304 & $107.6 \mathrm{i}$ & $95.1 \mathrm{e}$ \\
\hline FT-7 & $106.4 \mathrm{i}$ & $83.9 \mathrm{f}$ \\
\hline FT-Jatobá & $105.2 \mathrm{i}$ & $88.7 \mathrm{e}$ \\
\hline BR-37 & $105.2 \mathrm{i}$ & $121.7 \mathrm{~b}$ \\
\hline EMGOPA-309 & $104.9 \mathrm{i}$ & $121.4 \mathrm{~b}$ \\
\hline Embrapa 5 & $101.3 \mathrm{j}$ & $105.9 \mathrm{~d}$ \\
\hline FT-9 & $100.9 \mathrm{j}$ & $82.9 \mathrm{f}$ \\
\hline Embrapa 20 & $99.7 \mathrm{j}$ & $171.8 \mathrm{a}$ \\
\hline FT-14 & $99.7 \mathrm{j}$ & 47.91 \\
\hline Embrapa 2 & $96.3 \mathrm{j}$ & $80.7 \mathrm{f}$ \\
\hline CV (\%) & 1.6 & 2.9 \\
\hline
\end{tabular}

such as soaking and fermentation when the enzime $\beta$-glucosidases is activated (Matsuura et al., 1989; Coward et al., 1993). This suggests that for a significative correlation between substrate and enzyme, the soybean grains should be exposed to other conditions to express this effect.

The average $\beta$-glucosidase activity in cultivar IAS 5 sowed in different locations of the states of Rio Grande do Sul, Paraná and Mato Grosso do Sul was not different $(132.1,131.9,132.5$ units, respectively) (Table 2). These results suggest that environmental conditions did not affect enzyme activity in the average of locations. Isoflavone glucosides in cultivar IAS 5, however, were strongly affected by the environment $(178.8,131.4$, $85.5 \mathrm{mg} / 100 \mathrm{~g}$ for Rio Grande do Sul, Paraná and Mato Grosso do Sul, respectively). For each location within the states there was a significant variability in enzyme activity. In Rio Grande do Sul, $\beta$-glucosidase activities were 137.6 and 124.8 units, in the locations of Santa Rosa and Vacaria, respectively. This situation was completely reverse for the concentration of isoflavone glucosides (Table 2), and a nonsignificative correlation was observed between these compounds and enzyme activity $(r=-0.2)$. In spite of statistical differences among locations, it could be considered that differences of 10 units observed in average were small to consider enzyme activity differences due to conditions of sowing locations. Larger differences could be more effective in the enzyme activity.

Results indicated no correlation between levels of isoflavone glucosides and enzyme activity. Other parameters than grain raw material must be observed in $\beta$-glucosidase activity. By comparing content of isoflavone aglycones between fermented and non fermented soybean products, it can be inferred that processing technology is a determinant factor to activate the enzyme. Fermented soyfoods present higher concentrations of isoflavone aglycones (Coward et al., 1993; Wang \& Murphy, 1994b).

Optimum conditions for $\beta$-glucosidase activity such as soaking grains at $45^{\circ} \mathrm{C}$ temperature (Matsuura et al., 1995) should be observed during soybean processing in order to obtain higher concentrations of genistein, which is the main aglycone form with anticancer activity (Peterson \& Barnes, 1993; Steele et al., 1995) and the most active compound in astringency perceived in the soybean flavor. 
TABLE 2. Mean values of $\beta$-glucosidase activity ( $\mathrm{mg}$ of $\mathrm{p}$-nitrophenol/100 $\mathrm{g}$ of samples $/ 2.5 \mathrm{hours}$ ) and total isoflavone glucosides in cultivar IAS 5 sowed in different locations, in 1993/94 $(n=3)^{1}$.

\begin{tabular}{|c|c|c|c|c|}
\hline State & Location & $\begin{array}{l}\text { Latitude } \\
\text { south }\end{array}$ & $\begin{array}{l}\beta \text { - glucosidase } \\
\text { activity }\end{array}$ & $\begin{array}{l}\text { Total isoflavone } \\
\text { glucosides }^{2}\end{array}$ \\
\hline \multirow{4}{*}{$\begin{array}{l}\text { Rio Grande } \\
\text { do Sul }\end{array}$} & Santa Rosa & $27^{\circ} 53^{\prime}$ & $137.6 \mathrm{a}$ & $126.9 \mathrm{c}$ \\
\hline & Passo Fundo & $28^{\circ} 17^{\prime}$ & $133.4 \mathrm{a}$ & 196.1a \\
\hline & Cruz Alta & $28^{\circ} 38^{\prime}$ & $132.5 \mathrm{ab}$ & $173.7 \mathrm{~b}$ \\
\hline & Vacaria & $28^{\circ} 30^{\prime}$ & $124.8 \mathrm{~b}$ & $218.7 \mathrm{a}$ \\
\hline Mean & & & $132.1 \mathrm{~A}$ & $178.8 \mathrm{~A}$ \\
\hline \multirow[t]{6}{*}{ Paraná } & Mariópolis & $26^{\circ} 21^{\prime}$ & $138.2 \mathrm{a}$ & $145.1 \mathrm{a}$ \\
\hline & Campo Mourão & $24^{\circ} 02^{\prime}$ & $135.0 \mathrm{a}$ & $115.0 \mathrm{ab}$ \\
\hline & Palotina & $24^{\circ} 27^{\prime}$ & $132.3 \mathrm{ab}$ & $105.9 \mathrm{~b}$ \\
\hline & Londrina & $23^{\circ} 11^{\prime}$ & $130.5 \mathrm{ab}$ & $142.6 \mathrm{a}$ \\
\hline & Ponta Grossa & $25^{\circ} 05^{\prime}$ & $128.8 \mathrm{ab}$ & $143.4 \mathrm{a}$ \\
\hline & Cascavel & $24^{\circ} 58^{\prime}$ & $126.8 \mathrm{~b}$ & $136.5 \mathrm{a}$ \\
\hline Mean & & & $131.9 \mathrm{~A}$ & $131.4 \mathrm{~B}$ \\
\hline Mato Grosso & Campo Grande & $20^{\circ} 28^{\prime}$ & $138.8 \mathrm{a}$ & $93.2 \mathrm{a}$ \\
\hline \multirow{2}{*}{ do Sul } & Sidrolândia & $20^{\circ} 56^{\prime}$ & $129.8 b$ & $69.6 \mathrm{a}$ \\
\hline & S. Gabriel Oeste & $19^{\circ} 21^{\prime}$ & $129.0 \mathrm{~b}$ & $93.8 \mathrm{a}$ \\
\hline Mean & & & $132.5 \mathrm{~A}$ & $85.5 \mathrm{C}$ \\
\hline CV (\%) & & & 3.3 & 9.2 \\
\hline
\end{tabular}

1 Values of the interaction between location and cultivar, fixed within the state, followed by the same small letters in the columns are not significantly different at 5\% probability level (Tukey, 1949); values of the interaction between state and cultivar, followed by the same capital letters in the columns are not significantly different at $5 \%$ probability level (Tukey, 1949).

${ }^{2}$ Carrão-Panizzi (1996b).

\section{CONCLUSIONS}

1. Soybean cultivars present variability for $\beta$-glucosidase activity.

2. $\beta$-glucosidase activity does not correlate with concentration of isoflavone glucosides in raw soybean grains.

3. Environmental conditions do not affect $\beta$-glucosidase activity, as they affect concentration of isoflavone glucosides among the states.

\section{ACKNOWLEDGEMENTS}

To Drs. N.E. Arantes, R.B. Rolim, P.F. Bertagnolli, N.L.Zuffo, A. Harada, and M.C. Meyer, for providing soybean seeds; to Dr. M.C.N. Oliveira and Dr. J. Erivaldo Pereira, for the statistical analysis; to Celso Fratias and Adriano Lima, for help with the field work; to Dr. K. Kitamura, for technical assistance; to Dr. A.R. Panizzi and Dr. J.M.G. Mandarino, for reading early drafts of the manuscript; to Conselho Nacional de Desenvolvimento Científico e Tecnológico (CNPq) and National Agriculture Research Center (NARC - Japan), for financial support.

\section{REFERENCES}

ADLERCREUTZ, H.; HONJO, H.; HIGASHI, A.; FOTSIS, T.; HAMALAINEN, E.; HASEGAWA, T.; OGAWA, $H$. Urinary excretion of lignans and isoflavonoid phytoestrogens in Japanese men and women consuming a traditional Japanese diet. American Journal of Clinical Nutrition, Bethesda, v.54, n.6, p.1093-1100, 1991.

BURR, I.W.; FOSTER, L.A. A test for equality of variances. West Lafayette : University of Purdue, 1972. 26p. (Mimeo Series, 282).

CARRÃO-PANIZZI, M.C. Avaliação de cultivares de soja quanto aos teores de isoflavonóides. Pesquisa Agropecuária Brasileira, Brasília, v.31, n.10, p.691-698, out. 1996a.

CARRÃO-PANIZZI, M.C. Isoflavonóides em soja (Glycine $\max (\mathbf{L}$.) Merrill): variabilidade genética e ambiental de cultivares e efeitos no processamento do extrato solúvel. Londrina : Universidade Estadual de Londrina, 1996b. 123p. Tese de Doutorado.

CARRÃO-PANIZZI, M.C.; KITAMURA, K. Isoflavone content in Brazilian soybean cultivars. Breeding Science, Tokyo, v.45, n.3, p.295-300, 1995.

Pesq. agropec. bras., Brasília, v.35, n.5, p.873-878, maio 2000 
COCHRAN, W.G.; COX, G.M. Experimental designs. New York: J. Willey, 1957. 601p.

COWARD, L.; BARNES, N.C.; SETCHELL, K.D.R.; BARNES, S. Genistein, daidzein, and their $\beta$-glycoside conjugates: antitumor isoflavones in soybean foods from American and Asian diets. Journal of Agricultural and Food Chemistry, Washington, v.41, n.11, p.1961-1967, 1993.

ELDRIDGE, A.; KWOLEK, W. Soybean isoflavones: effect of environment and variety on composition. Journal of Agricultural and Food Chemistry, Washington, v.31, n.2, p.394-396, 1983.

HA, E.Y.W.; MORR, C.V.; SEO, A. Isoflavone aglycones and volatile organic compounds in soybeans: effects of soaking treatments. Journal of Food Science, Chicago, v.57, n.2, p.414-417, 1992.

HARTLEY, H.O. Testing the homogeneity of a set of variances. Biometrika, v.31, n.314, p.249-255, 1940.

KITAMURA, K.; IGITA, K.; KIKUCHI, A.; KUDOU, S.; OKUBO, K. Low isoflavone content in early maturing cultivars, so-called Summer-type soybeans (Glycine max (L.) Merrill). Japanese Journal of Breeding, Tokyo, v.41, n.4, p.651-654, 1991.

KUDOU, S.; FLEURY, Y.; WELTI, D.; MAGNOLATO, D.; UCHIDA, T.; KITAMURA, K.; OKUBO, K. Malonyl isoflavone glycosides in soybean seeds (Glycine $\max (\mathrm{L}$.$) Merrill). Agricultural and$ Biological Chemistry Journal, Tokyo, v.55, n.9, p.2227-2233, 1991.

MATSUDA, S.; MIYAZAKI, T.; MATSUMOTO, Y.; OHBA, R.; TERAMOTO, Y.; OHTA, N.; UEDA, $\mathrm{S}$. Hydrolysis of isoflavones in soybean cooked syrup by Lactobacillus casei subsp. rhamnosus IFO 3425. Journal of Fermentation and Bioengineering, Osaka, v.74, n.5, p.301-304, 1992.

MATSUDA, S.; NORIMOTO, F.; MATSUMOTO, Y; OHBA, R.; TERAMOTO, Y.; OHTA, N.; UEDA, $\mathrm{S}$. Solubilization of a novel isoflavone glycosidehydrolyzing $\beta$-glucosidase from Lactobacillus casei subsp. rhamnosus IFO 3425. Journal of Fermentation and Bioengineering, Osaka, v.77, n.4, p.349-441, 1994.

MATSUURA, M.; OBATA, A. $\beta$-glucosidases from soybeans hydrolyse daidzin and genistin. Journal of Food Science, Chicago, v.58, n.1, p.144-147, 1993.

MATSUURA, M.; OBATA, A.; FUKUSHIMA, D. Objectionable flavor of soymilk developed during the soaking of soybeans and its control. Journal Food Science, Chicago, v.54, n.3, p.602-605, 1989.
MATSUURA, M.; SASAKI, J.; MURAO, S. Studies on $\beta$-glucosidases from soybeans that hydrolyse daidzin and genistin: Isolation and characterization of an isozyme. Bioscience, Biotechnology and Biochemistry, Tokyo, v.59, n.9, p.1623-1627, 1995.

MESSINA, M.; MESSINA, V.; SETCHELL, K. The simple soybean and your health. Garden City Park : Avery, 1994. 260p.

PETERSON, G.; BARNES, S. Genistein and biochanin A inhibit the growth of human prostate cancer cells but not epidermal growth factor receptor tyrosine autophosphorylation. The Prostate, New York, v.22, n.4, p.335-345, 1993.

PETERSON, G.; BARNES, S. Genistein inhibition of the growth of human breast cancer-cells: independence from estrogen receptors and the multi-drug resistance gene. Biochemical and Biophysical Research Communications, San Diego, v.179, n.1, p.661-667, 1991.

SAS INSTITUTE (Cary, United States). SAS proprietary software release 6.09. Cary, 1995. Disquetes.

SCOTT, A.J.; KNOTT, M. A Cluster analysis method for grouping means in the analysis of variance. Biometrics, Alexandria, v.30, n.3, p.507-512, 1974.

SHAPIRO, S.S.; WILK, M.B. An analysis of variance test for normality. Biometrika, London, v.52, n.314, p.591-611, 1965.

STEELE, V.E.; PEREIRA, M.A.; SIGMAN, C.C.; KELLOFF, G.J. Cancer chemoprevention agent development strategies for genistein. Journal of Nutrition, Bethesda, v.125, n.3s, p.713S-716S, 1995.

TUKEY, J.W. One degree of freedom for non-additivity. Biometrics, Alexandria, v.5, n.3, p.232-242, 1949.

WANG, H.; MURPHY, P. Isoflavone composition of American and Japanese soybeans in Iowa: effects of variety, crop year, and location. Journal of Agricultural and Food Chemistry, Washington, v.42, n.8, p.1674-1677, 1994a.

WANG, H.; MURPHY, P. Isoflavone content in commercial soybean foods. Journal of Agricultural and Food Chemistry, Washington, v.42, n.8, p.1666-1673, 1994b.

XU, X.; WANG, H.; MURPHY, P.A.; COOK, L.; HENDRICH, S. Daidzein is more bioavailable soymilk isoflavone than is genistein in adult women. Journal of Nutrition, Bethesda, v.124, n.6, p.825832, 1994.

ZONTA, E.P.; MACHADO, A.A.; SILVEIRA JÚNIOR, P.S. Sistema de Análise Estatística-SANEST, Pelotas, 1982. 63p. Registro na SEI N066060. 